\title{
Government Mass Communication in Asean Countries in Health Services during the Covid 19 Pandemic
}

\author{
Syefiq Marliaz ${ }^{1}$, Shahril Azih ${ }^{1}$ \\ ${ }^{1}$ Faculty of Arts and Social Science, University of Malaya, Malaysia
}

\begin{abstract}
The purpose of this study was to determine the role of government mass communication in ASEAN countries in health services during the COVID-19 pandemic. In an effort to increase awareness of COVID-19, the development of digital-based information is increasingly needed. The public needs credible and reliable information to find out the Covid-19 phenomenon and its various impacts. people are increasingly understanding ways to protect themselves, their families, and the environment appropriately. This will also affect the improvement of public health services by providing good education and guidelines in mass media communication in ASEAN countries, especially in improving health services to the community.
\end{abstract}

Keywords: Mass Communication, Health Services, Covid-19 Pandemic

Received: August 9, 2021

Revised: September 5, 2021

Accepted: September 23, 2021

\section{Introduction}

The number of COVID-19 cases in the region shows that every country in the region has similar problems. ASEAN, a regional institution in the Southeast Asia region that oversees 10 member countries and was established in 1967, has issued several regional initiatives to deal with the problem of the COVID-19 outbreak that is spreading in the region. One of the initiatives that member countries have successfully agreed on is the COVID-19 Response Funds. However, apart from the initiatives launched by ASEAN, the reality of international relations in the midst of a crisis will have implications for two possibilities, namely encouraging collaboration with other affected countries or actually carrying out restrictions for self-rescue known as mechanisms (self-help). The last possibility has been witnessed by the world today, some countries are restricting essential goods needed in the midst of a pandemic. Tensions between countries will increase and make countries take restrictive steps, this is influenced by the mass media which glorify the situation during the COVID-19 pandemic (Filipova, 2020).

Information is a human need. In the current technological era, various needs for information, education, entertainment, economy and access to knowledge can be more easily accessed by the public through various media (Yusof et al., 2019). This situation is motivated by the movement of change and progress that moves increasingly dynamically. In the global situation of the Corona Virus Disease 2019 (Covid-19) pandemic, the development of digital-based information is increasingly needed. The public needs credible and reliable information to find out the Covid-19 phenomenon and its various impacts (Falcone et al., 2020). In this way, people will understand more about how to properly protect themselves, their families, and the environment. This will also affect the improvement of public health services by providing good education and guidelines in mass media communication in ASEAN countries.

The government carried out a three-pronged strategy in handling outbreaks in this cluster, namely by implementing a social distancing strategy to suppress the spread of the outbreak, placing medical posts in each dormitory so that migrant workers who experienced health problems could be dealt with immediately, and finally, by implementing an aggressive testing 
regime. as well as world opinion regarding the Singapore Government's response in handling cases in the migrant worker cluster is one of the things that the Government pays attention to. World opinion that intersects with the aspect of inequality in the case of migrant workers in Singapore can have an impact on the position state credibility when issuing normative discourses at global meeting forums. Therefore, the Government through MOFA provides open information as a counter-opinion as well as an overview of the government's role in ensuring the lives and livelihoods of migrant workers in the midst of the COVID-19 outbreak.

\section{Challenges for health systems in Asean Countries during a Pandemic}

The number of patients who continue to grow, the shortage of personal protective equipment for health workers and limited facilities to provide intensive care add to concerns about transmission in areas that are difficult to control (Patel et al., 2017). The pandemic has put enormous pressure on Indonesia's healthcare system, with reports of inadequate medical supplies and hospital worker deaths as the numbers continue to rise. The hospital crisis looms as experts point out that the combined capacity of the 132 hospitals designated to treat Covid19 is far from adequate with protective equipment for under-supplied medical workers, and there are only 1,200 lung specialists across the country who are adept at screening. . respiratory disease caused by a virus. In response, the government recently converted four apartment towers from the 2018 Asian Games athletes' village in Jakarta into a makeshift hospital to treat around 24,000 Covid-19 patients. The country also received a boost on March 23 when a military transport plane landed from China carrying medical supplies, following earlier support from Singapore for personal protective equipment.

\section{CONFIRMED COVID-19 CASES AND DEATHS IN ASEAN}

\begin{tabular}{|rcccccc|}
\hline & $\begin{array}{c}\text { Total } \\
\text { Cases }\end{array}$ & $\begin{array}{c}\text { New } \\
\text { Cases }\end{array}$ & $\begin{array}{c}\text { Total } \\
\text { Deaths }\end{array}$ & $\begin{array}{c}\text { New } \\
\text { Deaths }\end{array}$ & $\begin{array}{c}\text { Total } \\
\text { Recovered }\end{array}$ & $\begin{array}{c}\text { Active } \\
\text { Cases }\end{array}$ \\
\hline Indonesia & 80,094 & $+1,522$ & 3,797 & +87 & 39,050 & 37,247 \\
\hline Philippines & 58,850 & $+1,392$ & 1,614 & +11 & 20,976 & 36,260 \\
\hline Singapore & 46,878 & +249 & 27 & +1 & 42,737 & 4,114 \\
\hline Malaysia & 8,734 & +5 & 122 & 0 & 8,526 & 86 \\
\hline Thailand & 3,232 & +5 & 58 & 0 & 3,092 & 82 \\
\hline Vietnam & 373 & 0 & 0 & 0 & 352 & 21 \\
\hline Myanmar & 337 & +1 & 6 & 0 & 261 & 70 \\
\hline Cambodia & 165 & 0 & 0 & 0 & 133 & 32 \\
\hline Brunei & 141 & 0 & 3 & 0 & 138 & 0 \\
\hline Lao PDR & 19 & 0 & 0 & 0 & 19 & 0 \\
\hline ASEAN & 198,823 & $+3,174$ & 5,627 & +99 & 115,284 & 77,912 \\
\hline
\end{tabular}

"Source: WHO et. al. as at 7:OOPM GMT +8 dated 15 July 2020.

Figure 1. Covid-19 Cases

In the Philippines, health officials admit limited testing for Covid-19 means that, like Indonesia, its already overwhelmed health system could reduce more infections the numbers show. The Philippine Congress convened a special session to consider expanding the powers 
of the government, including taking over private utilities, telecommunications and transportation operators or businesses in the public interest, and by forcing hotels and other establishments to accommodate medical workers or those who are quarantined. With the rapid increase in infections in Malaysia, the federal government has designated more than 400 new locations across the country as quarantine zones for Covid-19 patients including state universities, community colleges, training centres, polytechnics and government-owned hotels. Following a strained health care system due to the increasing number of cases, Mercy Malaysia launched the "Covid-19 Pandemic Fund" to support medical services and essential needs of marginalized groups in the country. In Thailand, the government established the Covid-19 Situation Command Center on March 12 in response to the Covid-19 situation, chaired by the Prime Minister. A budget of THB 6.3 billion from the central fund reserved for emergencies was approved on March 17, to mitigate and respond to the impact of Covid-19. This budget will be allocated to Ministries, specifically public health, transportation, higher education and innovation, defense and trade to support their activities. The Ministry of Health has supplied 1,000,000 surgical masks per day to hospitals. An additional 1.5 million N95 masks and 1.9 million personal protective equipment (PPE) will also be allocated. In addition, the Ministry will provide 40,000 Favipiravir pills and 220 doses of Remdesivir for the treatment of Covid19. Patients with general symptoms of Covid-19 or with a doctor's prescription are eligible for the free test.

Increased policy convergence and a more unified regional response are facilitated by discussions within the context of ASEAN and its existing response mechanisms. High-level ASEAN officials met in early January to prepare for a region-wide response to the rapid spread of Covid-19. According to the post-2015 ASEAN health sector agenda, there are at least seven mechanisms designed to support regional preparedness and response by ASEAN Plus Three.

Since the first report from China of unexplained pneumonia clusters on January 3, the Senior Officials Meeting for Health Development (SOMHD) mobilized these different mechanisms to respond to the pandemic. The ASEAN Network of Emergency Operations Centers for public health emergencies (ASEAN EOC Network) has shared daily situational updates and provided information on prevention, detection and response measures to the ASEAN SOMHD (Plus Three Countries), as well as the Contact Points of the ASEAN EOC Network and Epidemiology Training Network. ASEAN Plus Tiga (ASEAN+3 FETN) Field. The ASEAN BioDioaspora Regional Virtual Center (ABVC) for big data analytics and visualization recently produced a Risk Assessment report for the International Spread of Covid-19 across the ASEAN Region, complementing the national risk assessment.

\section{The Importance of Government Mass Media Communication}

The press is urgently needed by the state as the frontline in disseminating information on the handling of the pandemic, the press must be saved in the current crisis situation as a long-term investment for democracy and good governance in Indonesia, the press needs economic incentives from the state to stay alive and carry out its functions properly (Maduro \& Kahn, 2020). This situation of uncertainty still overshadows the global and homeland situation due to the Covid-19 pandemic, so that the government must always be alert and sensitive in anticipating socio-economic vulnerabilities as a result of the pandemic. We know that the economic crisis triggered by the Covid-19 pandemic has forced the government to make various regulations and policies, including launching stimulus policies through the National Economic Recovery program that can have a positive impact on the national economy.

\section{Government Mass Communication Management}


Managing public communication during the Covid-19 pandemic is not easy but it must be done to provide understanding to the public so they know better how to deal with problems that are also faced because various responses that arise can trigger panic and ultimately change people's behavior. For this reason, the delivery of information to the public is also expected to use media that can be accessed by various groups of people. Therefore, in providing public information and communication services, writers from the local government, private sector and members of the press are expected to be able to convey information using simple and easy-to-understand language so that the public can accept and understand the provisions and rules taken by the government in order to break the chain of the spread of Covid. -19.

The communication is expected to reach all levels of society including vulnerable groups ranging from women, female heads of households, persons with disabilities, the elderly, ethnic minorities, PLWHA, and others. Likewise, the communication strategy in the middle and upper classes of society is to build a solidarity movement to help each other, share with one another as a collective struggle movement. Every policy issued certainly has an impact on the wider community and must be anticipated for all possibilities that can lead to socio-economic turmoil at the local level.

\section{The Effectiveness of Mass Communication in Improving Health Services during the Pandemic}

Effective communication with the public is critical to managing an outbreak (Zhang \& Chen, 2020). Communication during an outbreak is a significant leap forward for strategic policy making. In addition, maintaining the trust of the media and the general public is critical to ensuring compliance with public health measures. To build trust, the government's response to an emergency must appear competent, credible and orderly. Social media communication is effective during the covid-19 pandemic crisis. For example, to display progress data related to the COVID-19 pandemic. As the covid-19 pandemic has an immediate local impact, communication about the dangers must start locally.

In an emergency situation of the covid-19 pandemic, communication is needed as a function of management and coordination between the government, victims, communities, volunteers, and the mass media (Drury et al., 2021). Proper crisis communication management will make government coordination, and decision-making function run stable. On the victim's side, suffering can be reduced because assistance is faster and easier to provide with adequate information capital. It is very important for the victim's family and the wider community to fulfill the need for information about the current condition and condition of the victim, both survivors and those who died, to avoid anxiety. Volunteers also really need smooth communication with various parties to be able to go to the location of the COVID-19 pandemic. Whereas the mass media in an emergency need a credible source of information so that the news that is disseminated will benefit the wider community. To build good communication in dealing with the COVID-19 pandemic, the government and all elements must work together and establish good cooperation. In addition, several important foundations must be considered if the treatment is to be effective.

\section{Conclusion}

In the current technological era, various needs for information, education, entertainment, economy and access to knowledge can be more easily accessed by the public through various media. This situation is motivated by the movement of change and progress that moves increasingly dynamically. In the global situation of the Corona Virus Disease 2019 (Covid-19) pandemic, the development of digital-based information is increasingly needed. International 
relations in the midst of a crisis will have implications for two possibilities, namely encouraging collaboration with fellow affected countries or actually carrying out restrictions for self-preservation known as mechanisms (self-help). The pandemic has put enormous stress on the healthcare system with reports of inadequate medical supplies and hospital worker deaths as the numbers continue to rise. The last possibility has been witnessed by the world today, some countries are restricting essential goods needed in the midst of a pandemic. Challenges that occur during the pandemic can be reduced because assistance is faster and easier to provide with adequate information capital. In providing public information and communication services, writers from the government, private sector and press are expected to be able to convey information using simple and easy-to-understand language so that the public can accept and understand the provisions and rules taken by the government in order to break the chain of the spread of Covid-19.

\section{References}

Drury, J., Carter, H., Ntontis, E., \& Guven, S. T. (2021). Public behaviour in response to the COVID-19 pandemic: understanding the role of group processes. BJPsych open, 7(1).

Falcone, R., Colì, E., Felletti, S., Sapienza, A., Castelfranchi, C., \& Paglieri, F. (2020). All we need is trust: How the COVID-19 outbreak reconfigured trust in Italian public institutions. Frontiers in Psychology, 11.

Filipova, R. (2020). The Shrinking Space for Media Freedom in Southeast Europe in the Midst of Covid-19 Pandemic and State of Emergency. Центьр за изследване на демокрацията.

Maduro, M. P., \& Kahn, P. W. (Eds.). (2020). Democracy in times of pandemic: Different futures imagined. Cambridge University Press.

Patel, A., D'Alessandro, M. M., Ireland, K. J., Burel, W. G., Wencil, E. B., \& Rasmussen, S. A. (2017). Personal protective equipment supply chain: lessons learned from recent public health emergency responses. Health security, 15(3), 244-252.

Yusof, A. A., Adnan, A. H. M., Mustafa Kamal, N. N., Mohd Kamal, M. A., \& Ahmad, M. K. (2019, February). Education 4.0 immersive learning with Spherical Videos (360) and Virtual Reality (VR) experiences. In Proceedings of the International Invention, Innovative \& Creative (InIIC) Conference, Series (pp. 52-60).

Zhang, L., Li, H., \& Chen, K. (2020, March). Effective risk communication for public health emergency: Reflection on the COVID-19 (2019-nCoV) outbreak in Wuhan, China. In Healthcare (Vol. 8, No. 1, p. 64). Multidisciplinary Digital Publishing Institute 